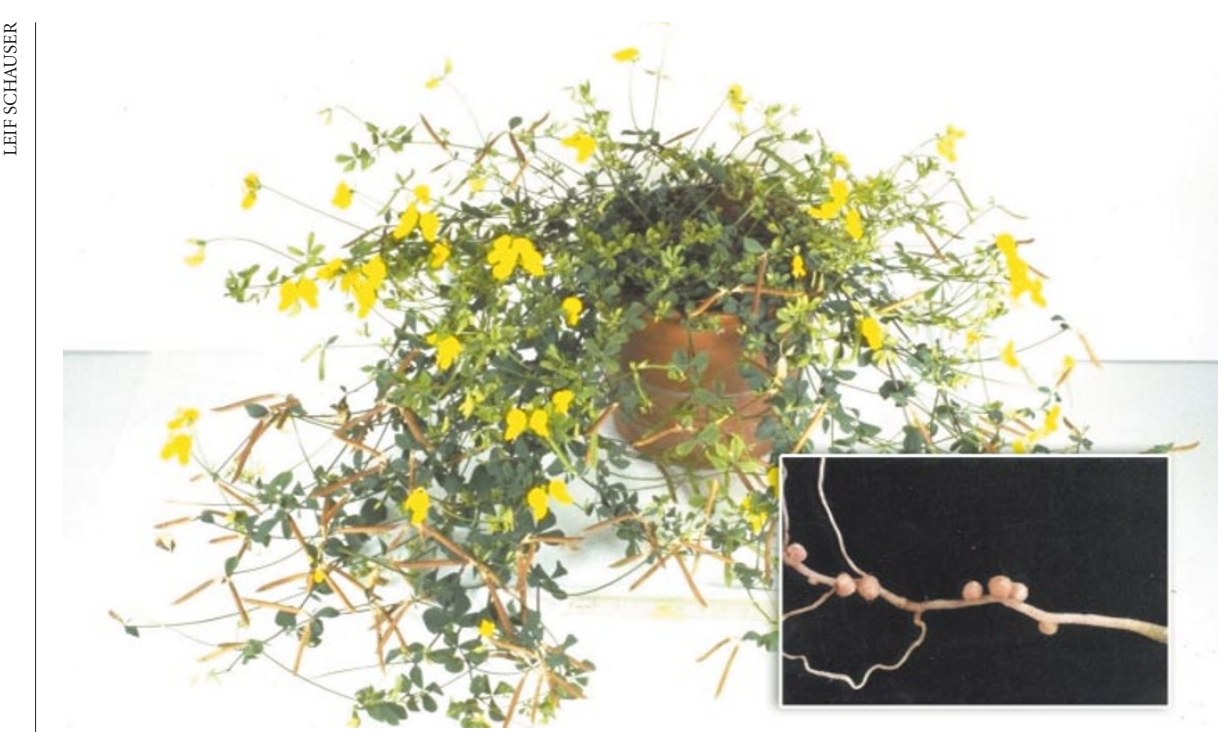

Rooting for success: Lotus japonicus benefits from the bacteria living in its root nodules (inset).

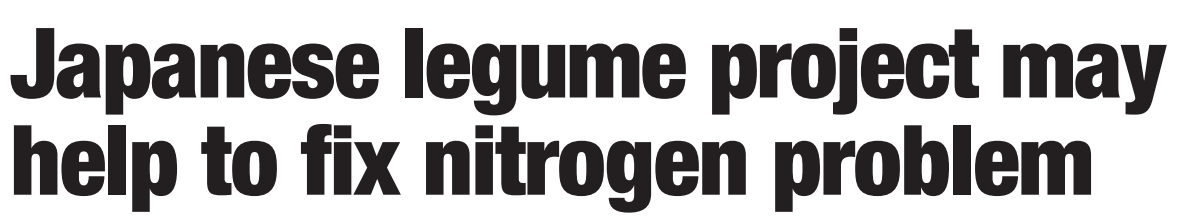

David Cyranoski, Tokyo

The mysterious relationship between legume-type plants and the nitrogen-fixing bacteria they harbour is to be investigated in a Japanese genome-sequencing project.

The nitrogen-grabbing function of the bacteria, which act in beans and other legumes, is of particular interest to researchers because it might replace highnitrogen fertilizers as a means of accelerating plant growth. And nitrogen pollution of land and waterways is emerging as a major problem in Europe, east Asia and other intensively farmed regions of the world.

Japan's Kazusa DNA Research Institute in Chiba, a small agricultural district outside Tokyo, has already sequenced the genome of one bacterium involved, Mesorhizobium loti. It is now taking on the task of sequencing the associated legume, Lotus japonicus.

Satoshi Tabata, who heads the project, believes that unravelling the two genomes will lead to a better understanding of nitrogen fixation - the conversion of inorganic nitrogen from soil into organic nitrogen that plants can use for growth. Researchers may eventually use the genetic information to optimize nitrogen fixation in legumes, and perhaps apply it to other plants.

Plants cannot themselves fix nitrogen, but legumes and some other plant varieties have developed a symbiotic relationship with bacteria that can absorb nitrogen from the soil. The bacteria receive shelter and nutrients from the plant in exchange for nitrogen.

Researchers believe the fixation process involves several steps. First, the plant and bacterium undergo a recognition process, in which each notes the each other's presence by emitting chemical signals. The plant reacts to the bacterial signal by developing root 'nodules'. Once the bacteria have been taken up into the specialized nodule cells, they begin nitrogen fixation.

Tabata says the project will help to identify the genes that enable the plant and bacterium to recognize each other and the plant genes that control nodule formation.

Ultimately, some of these genes could be used in unrelated plants, such as corn and wheat, spurring 'natural' nitrogen fixation and alleviating the need for the current heavy use of high-nitrogen fertilizers.

Tabata's approach to the sequencing problem is to focus on sequences in the genome that are similar to genes of known function. This will provide useful information even before the genome is complete, he says. Jens Stougaard of the Laboratory of Gene Expression at the University of Aarhus in Denmark, which studies gene function by and other plants, says Kazusa's work is "laying out the path for the rest of us to follow".

Furthermore, according to Tabata, $L$. japonicus could serve as a model for other legumes that are agriculturally important but difficult to study. Its genome is only about 450 megabases, about two-fifths the size of its more celebrated cousin, the soy bean. And its fast maturation and small size make it a convenient experimental plant.

But at the current rate it could take 15 years to complete the sequence. The project is Tabata says he would like other groups to get involved, but finds most national governments want to focus directly on crop plants. examining mutated versions of $L$. japonicus funded by the Chiba regional government.

\section{South Africa reveals funding allocations for research}

\section{Michael Cherry, Cape Town}

South Africa has announced how it will split university research funding for nine focus areas, which it selected last year. The areas were chosen in an effort to tie research more closely to societal needs.

The allocations (see table) are expected to form the basis for funding by the National Research Foundation (NRF) over the next five years, although grants will be awarded on an annual basis.

Half of this year's NRF budget of R162 million (\$20.5 million) will go to peerreviewed grants for established researchers. The rest will be allocated to other programmes such as the development of new research capacity at technical colleges and historically black universities.

Gerhard von Gruenewaldt, vicepresident of the NRF, says that funds were allocated to reflect the value of grant applications received in each area. This 'bottom-up' approach ensures that the government is not dictating a research agenda, he says.

Not all researchers in the country are thrilled with the outcome, and von Gruenewaldt admits that the available funding will support only $70 \%$ of the projects that the agency wanted to approve. "This presents us with the challenge of raising a substantial amount of additional resources over the next few years to meet these demands," he says.

But some researchers complain that the NRF reallocated their proposals into the wrong focus area. Ed Rybicki, a microbiologist at the University of Cape Town, says that this happened to him, and that his proposal was consequently underfunded. "I think the whole process is arbitrary and badly thought out," he says.

\begin{tabular}{|c|c|c|}
\hline & $\begin{array}{c}\text { NRF FOCUS AREAS } \\
2001-2005\end{array}$ & $\begin{array}{l}\text { Rand } \\
\text { million }\end{array}$ \\
\hline 1 & Strategic knowledge & 16.5 \\
\hline 2 & $\begin{array}{l}\text { Distinct South African } \\
\text { research opportunities }\end{array}$ & 5 \\
\hline 3 & Economic competitiveness & 21 \\
\hline 4 & Poverty eradication & 8 \\
\hline 5 & Ecological conservation & 12.5 \\
\hline 6 & Information technology & 4 \\
\hline 7 & $\begin{array}{l}\text { Socio-political impact } \\
\text { of globalization }\end{array}$ & 1 \\
\hline 8 & Education & 5 \\
\hline 9 & Indigenous knowledge & 10 \\
\hline & $\begin{array}{l}\text { Is: the areas were chose } \\
\text { o South Africa's social n }\end{array}$ & \\
\hline
\end{tabular}

